\title{
ANALISIS KOMPOSISI IDEAL DANA TABARRU'-UJRAH METODE DYNAMIC FINANCIAL ANALYSIS PERUSAHAAN ASURANSI JIWA SYARIAH DI INDONESIA ${ }^{1]}$
}

\author{
Billy Purwocaroko N \\ Program Studi Ekonomi Islam-Fakultas Ekonomi dan Bisnis-Universitas Airlangga \\ Email: billy.purwocaroko-12@feb.unair.ac.id \\ Noven Suprayogi \\ Departemen Ekonomi Syariah-Fakultas Ekonomi dan Bisnis-Universitas Airlangga \\ Email: noven.suprayogi@feb.unair.ac.id
}

\begin{abstract}
:
The aim of this study was to determine the ideal composition of tabarru'-ujrah fund on Sharia Life Insurance company in Indonesia through Dynamic Financial Analysis method. This research is a quantitative with a simulation approach. The simulation model was Monte Carlo simulation. The data using a secondary data from the financial statements of insurance sharia life insurance companies published between 2012-2014. There are two variables that influence the formation of the composition tabarru' the claims and Retakaful. The results of this study indicate that the ideal composition tabarru'-ujrah funds obtained amounted to 68.73\%: 31.27\%. The phenomenon that occurs is the composition tabarru' which showed a reading below 50\%, the life insurance industry sharia set much ujrah in every contribution at the time of composition claims and Retakaful in a low position, and ROI DPS received until the end of the forecasting declining and even minus.
\end{abstract}

Keywords : Sharia Life Insurance, The Ideal Composition of Tabarru'-Ujrah fund, Dynamic Financial Analysis, Financial Performance

\section{PENDAHULUAN}

Konsep dasar Asuransi Syariah

adalah usaha melindungi antar sesama peserta melalui investasi dalam bentuk Dana Tabarru' yang dikelola dengan akad syariah oleh perusahaan Asuransi Syariah (Fatwa DSN-MUI No:21/DSNMUI/X/2001 dalam Soemitra, 2009:255). Berdasarkan konsep Asuransi Syariah, tugas dan fungsi utama perusahaan Asuransi Syariah adalah sebagai wakil atau pengelola Dana Tabarru' yang diatur dalam dua Fatwa DSN-MUI yakni Fatwa DSN-MUI No. 52/DSN-MUI/III/2006 tentang akad Wakalah Bil Ujrah pada Asuransi dan Reasuransi Syariah dan Fatwa DSN-MUI No. 53/DSN-MUI/III/2006 tentang akad Tabarru'pada Asuransi dan Reasuransi Syariah, dimana pengelolaan antara

Dana Tabarru' dengan Dana Ujrah berbeda perlakuannya.

Akad Tabarru' adalah akad yang terjadi dalam hubungan antara sesama peserta atau pemegang polis dimana peserta memberikan hibah kepada peserta lain yang terkena musibah. Akad ini tidak bertujuan untuk mencari keuntungan. Sementara, akad Wakalah bil Ujrah mengatur hubungan antara peserta atau pemegang polis dengan perusahaan Asuransi. Dana Peserta Tabarru' (DPT) hanya digunakan ketika peserta membutuhkannya yang ditunjukkan melalui klaim. Perusahaan tidak berhak menggunakannya, dan hanya boleh mengelolanya. Ujrah Fee didapatkan oleh Perusahaan dari pengelolaan yang dilakukannya terhadap

1] Jurnal ini merupakan bagian dari skripsi dari Billy Purwocaroko N., NIM: 041211432102, yang diuji pada tanggal 10 Februari 2016 
Purwocaroko, et al/Jurnal Ekonomi Syariah Teori dan Terapan Vol. 3 No. 2 Februari 2016:158-172; ANALISIS KOMPOSISI IDEAL DANA TABARRU'-UJRAH METODE DYNAMIC FINANCIAL ANALYSIS PERUSAHAAN ASURANSI JIWA SYARIAH DI INDONESIA

Dana Peserta Tabarru' (DPT) dan menjadi Dana Pemegang Saham (DPS). Fenomena yang terjadi di Indonesia saat ini adalah adanya perbedaan dalam penentuan komposisi Dana Peserta Tabarru' dan Dana Pemegang saham baik perusahaan asuransi yang berbentuk Badan Usaha Syariah (BUS) maupun Unit Usaha Syariah (UUS) seperti apa yang ada dalam tabel.

Tabel 1.

Rasio Dana Pemegang Saham dengan Dana Peserta Tabarru' Per Desember 2013

\begin{tabular}{|c|c|c|c|}
\hline \multirow{2}{*}{ NO } & \multirow{2}{*}{$\begin{array}{c}\text { Perusahaan } \\
\text { Asuransi Jiwa } \\
\text { Syariah }\end{array}$} & \multicolumn{2}{|c|}{ Rasio (\%) } \\
\cline { 3 - 4 } & $\begin{array}{c}\text { DPS } \\
\text { ST. Asuransi Takaful } \\
\text { Keluarga }\end{array}$ & 77,07 & 22,93 \\
\hline 2 & $\begin{array}{c}\text { PT. Asuransi Jiwa } \\
\text { Syariah Al Amin }\end{array}$ & 51,33 & 48,67 \\
\hline 3 & $\begin{array}{c}\text { PT. Asuransi Jiwa } \\
\text { Amanah Giri Artha }\end{array}$ & 82 & 18 \\
\hline 4 & $\begin{array}{c}\text { Asuransi Jiwa } \\
\text { Bersama } \\
\text { Bumiputera 1912 }\end{array}$ & 80,26 & 19,74 \\
\hline 5 & $\begin{array}{c}\text { PT. Prudential Life } \\
\text { Assurance }\end{array}$ & 88,44 & 11,56 \\
\hline
\end{tabular}

Sumber : Statistik Perasuransian 2013,www.ojk.go.id

Puspitasari (2011:128) menyatakan bahwa komposisi Tabarru' dipengaruhi oleh kegiatan klaim peserta dan retakaful perusahaan pada perusahaan Asuransi Umum Syariah. Jika komposisi Dana Tabarru' dengan Dana Ujrah tidak dalam posisi yang baik dan ideal maka hal tersebut akan berpengaruh pada kondisi kepemilikan masing-masing aset tersebut dan kinerja keuangan Perusahaan Asuransi Syariah. Perbedaan kepemilikan aset tersebut berpengaruh pada kinerja keuangan masing-masing kelompok dana. Posisi perusahaan Asuransi Syariah mengharuskan pengelolaan dana di dalamnya harus menguntungkan kedua belah pihak, yakni Perusahaan Asuransi Syariah dan Peserta Asuransi Syariah.

Klaim dan Retakaful menjadi penting dalam menentukan likuditas dana tabarru'. Jika tingkat klaim terlalu tinggi atau terlalu rendah maka akan berpengaruh pada kesediaan dana tabarru'. Hal itu berlaku dalam retakaful, jika terlalu tinggi akan menimbulkan dana tabarru' yang tersedia untuk investasi dan claim range yang telah ditentukan oleh perusahaan akan melebar. Jika retakaful terlalu rendah maka akan sedikit menghasilkan bagi hasil dalam pengelolaannya. Puspitasari (2015:198199) menyatakan bahwa selain klaim dan retakaful, internal perusahaan asuransi syariah juga mempunyai pengaruh dalam penentuan komposisi Tabarru' dan Ujrah, yakni Operational Expenses, Marketing Fee, dan Expected Margin

Analisis Keuangan Dinamis atau DFA (Dynamic Financial Analysis). Analisis Keuangan Dinamis atau DFA merupakan pendekatan sistematis dengan fungsi model keuangan yang memproyeksikan hasil finansial dalam berbagai kemungkinan skenario, menunjukkan hasil tersebut mungkin dipengaruhi oleh perubahan bisnis, persaingan dan kondisi ekonomi (Cripe. et al., 1996) dalam (Bergbaver, 2004) dalam (Puspitasari, 2011:129). 
Purwocaroko, et al/Jurnal Ekonomi Syariah Teori dan Terapan Vol. 3 No. 2 Februari 2016:158-172; ANALISIS KOMPOSISI IDEAL DANA TABARRU'-UJRAH METODE DYNAMIC FINANCIAL ANALYSIS PERUSAHAAN ASURANSI JIWA SYARIAH DI INDONESIA

Penggunaan DFA sangat sering sekali diteliti dalam Asuransi Umum Konvensional, dan sangat jarang ditemukan penerapannya pada Asuransi Umum Syariah maupun Asuransi Jiwa Syariah. Penelitian pada Asuransi Umum Syariah yang dilakukan oleh Puspitasari (2011) merupakan penelitian pertama yang menerapkan Konsep DFA pada Asuransi Umum Syariah dalam bahasa Indonesia meskipun tidak pula ditemukan jurnal dan penelitian terpublikasi dalam bahasa inggris yang mengulas penerapan DFA pada Asuransi Umum Syariah.

Merujuk pada pemaparan di atas, maka peneliti tertarik mengajukan judul "Analisis Komposisi Ideal Dana Tabarru'-Ujrah Dengan Metode Dynamic Financial Analysis Pada Perusahaan Asuransi Jiwa Syariah di Indonesia" untuk mengetahui komposisi ideal dana Tabarru'-Ujrah dan pengaruhnya terhadap kinerja keuangan perusahaan Asuransi Jiwa Syariah.

Tujuan Penelitian ini adalah Untuk menganalisis komposisi ideal dana Tabarru'-Ujrah pada Perusahaan Asuransi Jiwa Syariah di Indonesia.

\section{LANDASAN PUSTAKA}

Tabel 2.

Tabel Perbedaan Asuransi Konvensional dengan Asuransi Syariah

\begin{tabular}{|l|c|c|}
\hline Keterangan & $\begin{array}{c}\text { Asuransi } \\
\text { Konvension- } \\
\text { al }\end{array}$ & $\begin{array}{c}\text { Asuransi } \\
\text { Syariah }\end{array}$ \\
\hline Pengawas- & Tidak Ada & Adanya \\
\hline
\end{tabular}

\begin{tabular}{|c|c|c|}
\hline Keterangan & $\begin{array}{c}\text { Asuransi } \\
\text { Konvension- } \\
\text { al }\end{array}$ & $\begin{array}{l}\text { Asuransi } \\
\text { Syariah }\end{array}$ \\
\hline $\begin{array}{l}\text { an Dewan } \\
\text { Pengawas } \\
\text { Syariah } \\
\text { (DPS) }\end{array}$ & & $\begin{array}{c}\text { Dewan } \\
\text { Pengawas } \\
\text { Syariah } \\
\text { menjamin } \\
\text { dan } \\
\text { mengawasi } \\
\text { produk yang } \\
\text { dipasarkan } \\
\text { tetap sesuai } \\
\text { dengan } \\
\text { syariah. } \\
\end{array}$ \\
\hline Akad & $\begin{array}{l}\text { Jual Beli } \\
\text { (Tijari) }\end{array}$ & $\begin{array}{l}\text { Tolong } \\
\text { Menolong } \\
\text { (Takafuli) }\end{array}$ \\
\hline $\begin{array}{l}\text { Investasi } \\
\text { Dana }\end{array}$ & $\begin{array}{l}\text { Berdasarkan } \\
\text { sistem } \\
\text { Bunga }\end{array}$ & $\begin{array}{l}\text { Berdasarkan } \\
\text { sistem } \\
\text { Mudharabah } \\
\text { (Bagi Hasil) }\end{array}$ \\
\hline $\begin{array}{l}\text { Kepemilik- } \\
\text { an Dana }\end{array}$ & $\begin{array}{c}\text { Dana yang } \\
\text { terkumpul } \\
\text { dari } \\
\text { nasabah } \\
\text { dalam } \\
\text { bentuk } \\
\text { premi } \\
\text { merupakan } \\
\text { milik } \\
\text { perusahaan; } \\
\text { perusahaan } \\
\text { bebas } \\
\text { menentuk- } \\
\text { an bentuk } \\
\text { dan } \\
\text { mekanisme } \\
\text { investasinya }\end{array}$ & $\begin{array}{c}\text { Dana yang } \\
\text { terkumpul } \\
\text { dari nasabah } \\
\text { dalam } \\
\text { bentuk premi } \\
\text { merupakan } \\
\text { milik peserta; } \\
\text { perusahaan } \\
\text { hanya } \\
\text { sebagai } \\
\text { pemegang } \\
\text { amanah } \\
\text { untuk } \\
\text { mengelola }\end{array}$ \\
\hline Klaim & $\begin{array}{l}\text { Dari } \\
\text { rekening } \\
\text { dana } \\
\text { perusahaan }\end{array}$ & $\begin{array}{l}\text { Dari rekening } \\
\text { tabarru' } \\
\text { (dana } \\
\text { kebajikan) } \\
\text { seluruh } \\
\text { peserta; } \\
\text { sejak awal } \\
\text { sudah } \\
\text { diikhlaskan } \\
\text { oleh peserta } \\
\text { untuk } \\
\text { keperluan } \\
\text { tolong } \\
\text { menolong } \\
\text { bila terjadi } \\
\text { musibah. }\end{array}$ \\
\hline Keuntung- & Seluruhnya & Dibagi \\
\hline
\end{tabular}


Punwocaroko, et al/Jurnal Ekonomi Syariah Teori dan Terapan Vol. 3 No. 2 Februari 2016:158-172; ANALISIS KOMPOSISI IDEAL DANA TABARRU'-UJRAH METODE DYNAMIC FINANCIAL ANALYSIS PERUSAHAAN ASURANSI JIWA SYARIAH DI INDONESIA

\begin{tabular}{|c|c|c|}
\hline Keterangan & $\begin{array}{c}\text { Asuransi } \\
\text { Konvension- } \\
\text { al }\end{array}$ & $\begin{array}{l}\text { Asuransi } \\
\text { Syariah }\end{array}$ \\
\hline an & $\begin{array}{l}\text { menjadi milik } \\
\text { perusahaan }\end{array}$ & $\begin{array}{c}\text { antara } \\
\text { perusahaan } \\
\text { denan } \\
\text { peserta } \\
\text { sesuai } \\
\text { dengan } \\
\text { prinsip bagi } \\
\text { hasil }\end{array}$ \\
\hline Konsep & $\begin{array}{c}\text { Perjanjian } \\
\text { antara dua } \\
\text { pihak atau } \\
\text { lebih, } \\
\text { dengan } \\
\text { mana pihak } \\
\text { penanggu- } \\
\text { ng } \\
\text { mengikatk- } \\
\text { an diri } \\
\text { kepada } \\
\text { tertanggu- } \\
\text { ng, dengan } \\
\text { menerima } \\
\text { premi } \\
\text { asuransi, } \\
\text { untuk } \\
\text { memberik- } \\
\text { an } \\
\text { pergantian } \\
\text { kepada } \\
\text { tertanggu- } \\
\text { ng. }\end{array}$ & $\begin{array}{c}\text { Sekumpulan } \\
\text { orang yang } \\
\text { saling bantu } \\
\text { membantu, } \\
\text { saling } \\
\text { menjamin, } \\
\text { dan } \\
\text { bekerjasama } \\
\text { antara satu } \\
\text { dengan } \\
\text { yang lainnya, } \\
\text { dengan cara } \\
\text { masing- } \\
\text { masing } \\
\text { mengeluark- } \\
\text { an dana } \\
\text { tabarru' }\end{array}$ \\
\hline Risiko & $\begin{array}{c}\text { Transfer Of } \\
\text { Risks }\end{array}$ & $\begin{array}{c}\text { Sharing Of } \\
\text { Risks }\end{array}$ \\
\hline
\end{tabular}

Sumber : Sudarsono, Heri. 2012. Bank dan Lembaga Keuangan Syariah : Deskripsi dan Ilustrasi. Edisi Ketiga. Yogyakarta : Ekonisia (diolah)

Menurut UU No. 2 Tahun 1992 tentang Usaha Perasuransian dalam Soemitra (2009:268-272) membagi asuransi menjadi tiga jenis yakni :

1. Asuransi Kerugian (Non Life

Insurance/General

Insurance/General Takaful)

Yakni usaha yang memberikan pelayanan jasa dalam penanggulangan risiko atas kerugian yang akan diderita oleh peserta, kehilangan manfaat dan tanggung jawab hukum kepada pihak ketiga yang timbul akibat peristiwa yang tidak terduga.

2. Asuransi Jiwa (Life Insurance/Family Takaful)

Jasa Asuransi yang diberikan kepada peserta oleh perusahaan dalam penanggulangan risiko yang dikaitkan dengan jiwa atau meninggalnya seseorang yang diasuransikan. Jenis risiko yang dihadapi dan dapat ditanggulangi yakni risiko kematian, risiko hari tua, dan risiko kecelakaan.

3. Reasuransi (Reinsurance/Retakaful)

Pemaknaan reasuransi dapat diambil dari KUHD Pasal 271 yang diintisarikan dari buku Principle of Insurance oleh Robert I. Mehr dan E. Cammark adalah : "Reinsurance is the Insurance of Insurance"(Hasan, 2014:127). Dengan kata lain, berdasarkan prinsip kepentingan yang dapat dipertanggungjawabkan, perusahaan asuransi dapat mempertanggungkan kembali kelebihan tanggung gugat yang diterimanya (excess liability) karena melampaui daya tampungnya sendiri (own retention) kepada penanggung lain.

Asuransi Jiwa Syariah adalah bentuk asuransi syariah yang utamanya memberikan layanan, perlindungan, dan bantuan menyangkut asuransi jiwa dan keluarga, untuk kesejahteraan masyarakat 
Punwocaroko, et al/Jurnal Ekonomi Syariah Teori dan Terapan Vol. 3 No. 2 Februari 2016:158-172; ANALISIS KOMPOSISI IDEAL DANA TABARRU'-UJRAH METODE DYNAMIC FINANCIAL ANALYSIS PERUSAHAAN ASURANSI JIWA SYARIAH DI INDONESIA

dengan berdasarkan landasan syariah (Hasan, 2014:135).

1. Sistem yang mengandung unsur tabungan

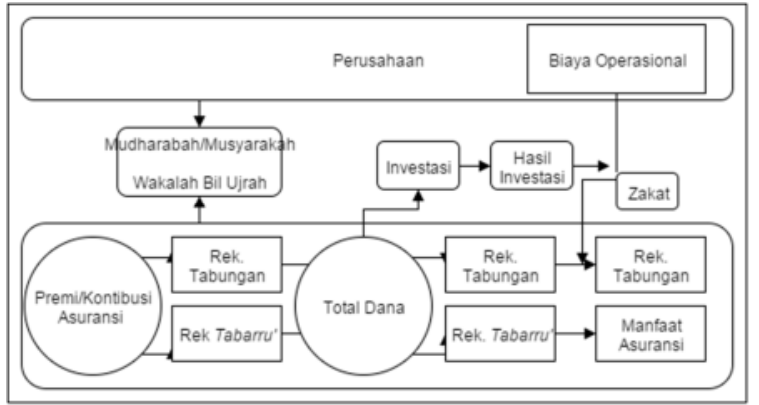

Sumber :Soemitra (2009:280)

\section{Gambar1.}

Mekanisme yang Mengandung Unsur Tabungan

2. Sistem yang tidak mengandung unsur tabungan

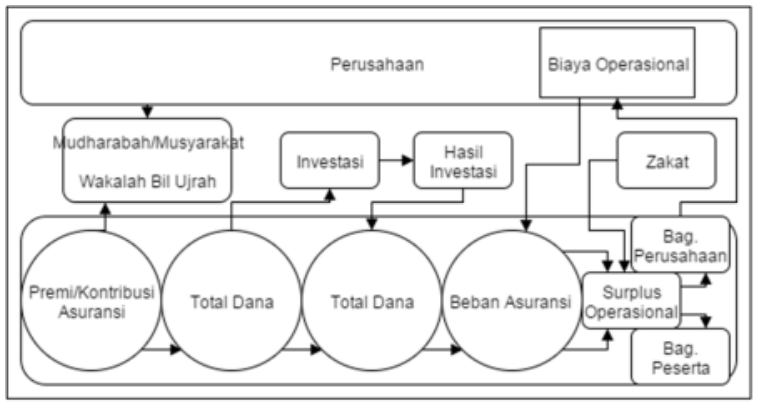

Sumber: Soemitra (2009:281)

Gambar 2.

\section{Mekanisme yang Tidak Mengandung} Tabungan

Setiap kumpulan dana ditujukan pada pencapaian tujuan, dan pelayanan dimasukkan dalam aset merupakan makna utama untuk mencapai tujuan tersebut. Fund Theory didasarkan pada persamaan :

Aset $=$ Pembatasan Aset (Restrictions of Assets)
Fund Theory memiliki kesamaan konsep dengan praktik pemisahan dana pada Asuransi Syariah (Split Fund), antara Dana Tabarru' yang dimiliki oleh peserta dan bertujuan untuk menolong sesama peserta dengan Dana Ujrah (Dana Pemegang Saham) yang dimiliki oleh perusahaan asuransi syariah sebagai imbalan dari pengelolaan dana. Kesamaannya adalah terdapat pada penekanan arus dana, dari mana sumber dana dan penggunaan dana digunakan untuk hal-hal yang sesuai dengan aturan dari sumber dana tersebut. Dalam praktik pemisahan dana pada asuransi syariah, Aset dan Kewajiban Dana Tabarru' hanya digunakna untuk kebutuhan peserta, sedangkan Aset dan Kewajiban Dana Pemegang Saham hanya digunakan untuk kebutuhan perusahaan.

Perusahaan Asuransi Syariah memiliki dua tugas dalam pengelolaan dana yakni dana Tabarru' milik peserta asuransi dan dana ujrah milik perusahaan asuransi sendiri. Dalam Bab II Ruang Lingkup Kesehatan Keuangan Pasal 2 Ayat 1 dan 2 PMK No. 11/PMK.010/2011 Tentang Kesehatan Kevangan Usaha Asuransi dan Usaha Reasuransi dengan Prinsip Syariah menyatakan bahwa Perusahaan harus menjaga kesehatan kevangan yang terdiri dari Dana Tabarru' dan Dana Perusahaan. Sedangkan untuk usaha asuransi jiwa syariah, perusahaan pun menjaga kesehatan keuangan Dana Investasi Peserta. 
Purwocaroko, et al/Jurnal Ekonomi Syariah Teori dan Terapan Vol. 3 No. 2 Februari 2016:158-172; ANALISIS KOMPOSISI IDEAL DANA TABARRU'-UJRAH METODE DYNAMIC FINANCIAL ANALYSIS PERUSAHAAN ASURANSI JIWA SYARIAH DI INDONESIA

Fatwa DSN-MUI No.53/DSN-MUI/III/2006 Tentang Akad Tabarru' disebutkan bahwa akad tabarru' adalah akad yang harus melekat pada seluruh produk asuransi syariah baik umum maupun jiwa dan retakaful. Akad tabarru' adalah jenis akad hibah yang dilakukan antar peserta asuransi syariah dan bukan bertujuan komersil. Dana tabarru' didapatkan dari peserta Asuransi Syariah yang membayar kontribusi premi. Dalam asuransi jiwa khususnya, pada saat peserta asuransi syariah membayar kontribusi premi maka akan diterapkan dua bentuk akad yakni akad tabungan investasi dan akad kontribusi. Akad tabungan investasi memiliki jenis akad tijari. Sedangkan akad kontribusi memiliki akad hibah (tabarru'). Keduanya tidak dapat digabungkan ke dalam wadah (pool) yang sama karena berbeda akad, dan tujuan. Setidaknya ada tiga hal yang mempengaruhi dana tabarru' yaitu :

\section{Klaim}

Klaim merupakan permintaan hak tangungan oleh peserta asuransi kepada perusahaan asuransi atas kontribusi yang telah dibayarkan selama periode berjalan. Klaim peserta asuransi merupakan salah satu variabel yang sangat mendukung berubahnya jumlah dana Tabarru' yang ada. Sehingga memuncukan dua kemungkinan yang terjadi yakni Underclaimed dan Overclaimed.

\section{Retakaful}

Definisi Retakaful tidak jauh berbeda dengan Reasuransi, yakni menanggungkan ulang suatuasuransi.

\section{Reasurans iFakultatif}

Reasuransi Fakultatif merujuk pada tidak adanya suatu keterikatan atau perjanjian antara pihak penanggung pertama (perusahaan asuransi) dengan pihak penanggung kedua (reasuransi/retakaful) dalam hal peralihan sejumlah risiko.

2. Reasuransi Berdasarkan Perjanjian atau Wajib

Reasuransi berdasarkan perjanjian atau wajib adalah jenis reasuransi atau retakaful dimana perusahaan penanggung pertama dengan perusahaan penanggung kedua memiliki keterikatan peralihan sejumlah risiko secara terus menerus hingga keterikatan tersebut berakhir atau diakhiri sesuai kemavan dan kemampuan kedua belah pihak penanggung. Reasuransi jenis ini dibagi menjadi empat jenis antara lain:

a. Reasuransi dengan perjanjian berdasarkan atas perbandingan (proporsional)

b. Reasuransi Quota Share

C. Reasuransi Surplus

d. Reasuransi dengan perjanjian yang tidak berdasarkan atas perbandingan (non proporsional)

3. Internal Perusahaan 
Punwocaroko, et al/Jurnal Ekonomi Syariah Teori dan Terapan Vol. 3 No. 2 Februari 2016:158-172; ANALISIS KOMPOSISI IDEAL DANA TABARRU'-UJRAH METODE DYNAMIC FINANCIAL ANALYSIS PERUSAHAAN ASURANSI JIWA SYARIAH DI INDONESIA

Prinsip yang dianut oleh perusahaan asuransi syariah hanyalah sebagai pengelola dana dan pembagi risiko peserta. Berdasarkan prinsip itu, perusahaan akan mendayagunakan seluruh perangkat yang ada di dalamnya untuk mengelola dana yang ada. Namun penggunaan seluruh perangkat tersebut memiliki dampak berupa kompensasi.

Puspitasari dalam disertasinya yang berjudul Shari'ah Split Fund Theory sebagai Refleksi Praktik Pemisahan Dana Bisnis Asuransi Umum Syariah (2011) menyatakan bahwa setidaknya selain variabel klaim dan retakaful, ada variabel internal perusahaan yang mempengaruhi penentuan komposisi Tabarru' dan Ujrah. Variabel internal perusahaan tersebut terdiri dari tiga yakni Operational Expenses, Marketing Fee, dan Expected Margin.

Dana Ujrah merupakan dana yang diperoleh perusahaan dari pemberlakuan akad Wakalah Bil Ujrah kepada peserta Asuransi Syariah sebagai imbalan dalam mengelola dana peserta. Dana Ujrah ini kemudian menjadi milik perusahaan asuransi syariah sepenuhnya dan akan masuk ke dalam Dana Pemegang Saham (DPS).

Penelitian ini bertujuan untuk menganalisis penentuan komposisi ideal dana Tabarru'-Ujrah pada asuransi jiwa syariah di Indonesia menggunakan metode Dynamic Financial Analysis (DFA). Metode ini diawali dengan membuat

model (modelling) lalu dilanjutkan dengan tahap simulasi. Simulasi yang dilakukan adalah simulasi monte carlo. Pada tahap pertama pembuatan model, ada tujuh variabel yang akan diuji pengaruhnya terhadap komposisi tabarru' dengan menggunakan analisis regresi berganda. Tujuh variabel tersebut adalah Klaim, Retakaful, dan Internal Perusahaan (Cadangan Qardhul Hasan, Biaya Komisi DPS, Biaya Umum dan Administrasi, Biaya Pemasaran, dan Biaya Pengembangan).

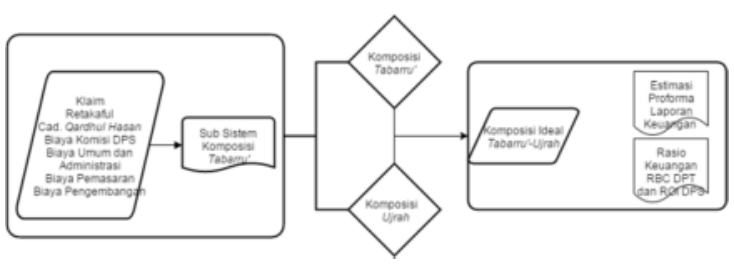

Gambar 3.

Model Analisis Dynamic Financial Analysis

\section{METODOLOGI PENELITIAN}

\section{Pendekatan Penelitian}

Penelitian ini dilakukan dengan menggunakan pendekatan kuantitatif. Pendekatan kuantitatif yang dimaksud adalah dengan menggunakan metode simulasi dengan tujuan eksperimentasi. Simulasi adalah suatu prosedur kuantitatif, yang menggambarkan sebuah sistem, dengan mengembangkan sebuah model dari sistem tersebut dan melakukan sederetan uji coba untuk memperkirakan perilaku sistem pada kurun waktu tertentu. Simulasi yang digunakan adalah Simulasi Monte Carlo.

\section{Identifikasi Variabel}


Purwocaroko, et al/Jurnal Ekonomi Syariah Teori dan Terapan Vol. 3 No. 2 Februari 2016:158-172; ANALISIS KOMPOSISI IDEAL DANA TABARRU'-UJRAH METODE DYNAMIC FINANCIAL ANALYSIS PERUSAHAAN ASURANSI JIWA SYARIAH DI INDONESIA

Variabel penelitian kuantitatif dibagi menjadi dua yakni variabel eksogen (variabel independen) dan variabel endogen (variabel independen). Penggunaan istilah eksogen dan endogen merujuk kepada penggunaan variabelvariabel penelitian yang melibatkan suatu sistem. Sistem tersebut dipengaruhi oleh kondisi eksogen sistem (luar sistem) maupun endogen sistem (dalam sistem). Variabel-variabel tersebut terdiri dari :

\section{Variabel Eksogen}

Variabel Eksogen adalah variabel yang menjadi pusat perhatian peneliti dan mempengaruhi variabel endogen. Variabel eksogen dalam penelitian ini adalah Klaim, Kegiatan Retakaful (Reasuransi), dan Internal Perusahaan.

\section{Variabel Endogen}

Variabel Endogen adalah variabel yang bereaksi ketika dihubungkan dengan variabel eksogen (independen). Variabel endogen dalam penelitian ini adalah Praktik Pemisahan Dana yang dibagi menjadi dua dimensi yakni dana peserta (dana tabarru') dan dana perusahaan (dana ujrah) dan pengukuran kinerja kevangan asuransi jiwa syariah yang diukur dari Risk Based Capital (RBC) Dana Peserta Tabarru' (DPT) dan Return On Investment (ROI) Dana Pemegang Saham (DPS).

\section{Definisi Operasional Variabel}

Tabel 3.

\section{Definisi Operasional Variabel}

\begin{tabular}{|c|c|c|}
\hline $\begin{array}{l}\text { Variab-el } \\
\text { Peneliti- } \\
\text { an }\end{array}$ & $\begin{array}{l}\text { Jenis } \\
\text { Vari- } \\
\text { abel }\end{array}$ & Definisi Operasional \\
\hline \multirow[t]{2}{*}{$\begin{array}{l}\text { Kompo- } \\
\text { sisi Dana } \\
\text { Tabarru' }\end{array}$} & \multirow[t]{2}{*}{ EN } & $\begin{array}{l}\text { Dana tabarru' adalah dana } \\
\text { yang sangat khas dalam asuransi } \\
\text { syariah. Dana tabarru' adalah } \\
\text { presentase dana yang berasal } \\
\text { dari kontribusi peserta asuransi } \\
\text { syariah dikurangi dana ujrah } \\
\text { sebagai imbalan perusahaan } \\
\text { asuransi syariah. }\end{array}$ \\
\hline & & $\begin{array}{c}1-K_{u}(\%) ; K_{u} \text { adalah Kontribusi } \\
\text { Ujrah }\end{array}$ \\
\hline \multirow[t]{2}{*}{$\begin{array}{l}\text { Kompo- } \\
\text { sisi Dana } \\
\text { Ujrah }\end{array}$} & \multirow[t]{2}{*}{ EN } & $\begin{array}{l}\text { Dana Ujrah sering disebut dana } \\
\text { perusahaan. Dana ujrah adalah } \\
\text { presentase dana yang berasal } \\
\text { dari kontribusi peserta asuransi } \\
\text { syariah dikurangi dana tabarru'. }\end{array}$ \\
\hline & & $\begin{array}{c}\text { 1-K } \mathrm{K}_{\mathrm{T}}(\%) ; \mathrm{K}_{\mathrm{T}} \text { adalah Kontribusi } \\
\text { Tabarru' }\end{array}$ \\
\hline \multirow[t]{2}{*}{ Klaim } & \multirow[t]{2}{*}{ EK } & $\begin{array}{l}\text { Klaim adalah mekanisme peserta } \\
\text { asuransi syariah kepada } \\
\text { penanggung (perusahaan } \\
\text { asuransi syariah) ketika terjadi } \\
\text { risiko yang tidak } \\
\text { menguntungkan. Besarnya rasio } \\
\text { klaim diperoleh dari besarnya } \\
\text { klaim yang terjadi dibandingkan } \\
\text { dengan kontribusi bruto. }\end{array}$ \\
\hline & & Rasio Klaim $=\frac{\text { Klaim }}{\text { Kontribusi Bruto }}$ \\
\hline \multirow[t]{2}{*}{ Retakaful } & \multirow[t]{2}{*}{ EK } & $\begin{array}{l}\text { Retakaful adalah usaha } \\
\text { perusahaan asuransi untuk } \\
\text { membagi sebagian resiko yang } \\
\text { diterimanya. Besarnya rasio } \\
\text { retakaful diperoleh dari besarnya } \\
\text { kontribusi retakaful yang } \\
\text { dilakukan dibandingkan dengan } \\
\text { kontribusi bruto yang diterima } \\
\text { perusahaan. }\end{array}$ \\
\hline & & $\begin{array}{l}\text { Rasio Retakaful } \\
=\frac{\text { Retakaful }}{\text { Kontribusi Bruto }}\end{array}$ \\
\hline $\begin{array}{l}\text { Internal } \\
\text { Perusaha } \\
\text { an }\end{array}$ & EK & $\begin{array}{c}\text { a. Cadangan Qardhul } \\
\text { Hasan } \\
\text { Cadangan Qardhul } \\
\text { Hasan adalah kekayaan yang } \\
\text { tersedia untuk Qardhyang } \\
\text { diberikan perusahaan asuransi } \\
\text { syariah kepada dana Tabarru' } \\
\text { jika terjadi kekurangan dana } \\
\text { Tabarru' dalam pemenuhan } \\
\text { klaim (overclaimed). } \\
\text { b. Biaya Komisi DPS } \\
\text { Biaya komisi adalah } \\
\text { besaran dana yang diberikan } \\
\text { oleh perusahaan asuransi syariah } \\
\text { kepada perusahaan pialang } \\
\text { asuransi, agen, bank dan/atau } \\
\text { perusahaan pembiayaan. } \\
\text { C. Biaya Umum dan } \\
\text { Administrasi } \\
\text { Biaya umum dan } \\
\text { administrasi adalah biaya yang } \\
\text { dikeluarkan perusahaan asuransi } \\
\text { syariah dalam melakukan } \\
\text { kegiatan operasionalnya sehari- }\end{array}$ \\
\hline
\end{tabular}


Punwocaroko, et al/Jurnal Ekonomi Syariah Teori dan Terapan Vol. 3 No. 2 Februari 2016:158-172; ANALISIS KOMPOSISI IDEAL DANA TABARRU'-UJRAH METODE DYNAMIC FINANCIAL ANALYSIS PERUSAHAAN ASURANSI JIWA SYARIAH DI INDONESIA

\begin{tabular}{|c|c|c|}
\hline $\begin{array}{l}\text { Variab-el } \\
\text { Peneliti- } \\
\text { an }\end{array}$ & $\begin{array}{l}\text { Jenis } \\
\text { Vari- } \\
\text { abel }\end{array}$ & Definisi Operasional \\
\hline & & $\begin{array}{c}\text { hari, baik gaji karyawan maupun } \\
\text { sewa bangunan. } \\
\text { d. Biaya Pemasaran } \\
\text { Biaya pemasaran } \\
\text { adalah besaran dana yang } \\
\text { dikeluarkan perusahaan asuransi } \\
\text { syariah dalam melakukan } \\
\text { kegiatan pemasaran berupa } \\
\text { promosi, iklan, dan kegiatan } \\
\text { konsumen. } \\
\text { e. Biaya Pengembangan } \\
\text { Biaya Pengembangan } \\
\text { adalah biaya yang dikeluarkan } \\
\text { sebagai bentuk pengembangan } \\
\text { pelayanan produk dan jasa oleh } \\
\text { perusahaan asuransi syariah. }\end{array}$ \\
\hline & & $\begin{array}{l}\text { Dapat dilihat di Laporan } \\
\text { Keuangan bagian kesehatan } \\
\text { keuangan dana perusahaan } \\
\text { dan laporan laba rugi dana } \\
\text { perusahaan }\end{array}$ \\
\hline \multirow[t]{3}{*}{ RBC DPT } & \multirow[t]{3}{*}{ EN } & $\begin{array}{c}\text { Risk Based Capital mengukur } \\
\text { seberapa besar tingkat } \\
\text { solvabilitas perusahaan asuransi } \\
\text { syariah. Penghitungannya } \\
\text { adalah Tingkat solvabilitas } \\
\text { (kekayaan yang diperkenankan } \\
\text { dikurangi kewajiban perusahaan) } \\
\text { dibandingkan dengan Batas } \\
\text { Tingkat Solvabilitas Minimum } \\
\text { (BTSM) } \\
\end{array}$ \\
\hline & & $\begin{array}{l}R B C \\
\text { Kekayaan yang diperkenankan }\end{array}$ \\
\hline & & BTSM \\
\hline \multirow[t]{2}{*}{ ROI DPS } & \multirow[t]{2}{*}{ EN } & $\begin{array}{l}\text { Return On Investment mengukur } \\
\text { seberapa besar kemampuan } \\
\text { perusahaan menggunakan } \\
\text { seluruh aktivanya dalam } \\
\text { menghasilkan keuntungan. ROI } \\
\text { didapatkan dari Laba bersih } \\
\text { setelah pajak (Earning After Tax) } \\
\text { dibagi dengan Investasi yang } \\
\text { dilakukan. }\end{array}$ \\
\hline & & $\begin{array}{l}\text { ROI } \\
=\frac{\text { Laba Bersih Setelah Pajak }}{\text { Investasi }}\end{array}$ \\
\hline $\begin{array}{l}\text { Sumber } \\
\text { berbagc }\end{array}$ & & itasari (2011), diolah \\
\hline
\end{tabular}

Keterangan :

$$
\mathrm{EN}=\text { Endogen } \mathrm{EK}=\text { Eksogen }
$$

\section{Jenis dan Sumber Data}

Jenis data dalam penelitian ini adalah Data Sekunder. Sumber data berasal dari Laporan Keuangan yang berupa Neraca dan Laporan Laba Rugi Perusahaan Asuransi Jiwa Syariah di Indonesia baik yang berbentuk Badan Usaha Syariah (BUS) maupun Unit Usaha Syariah.

\section{Teknik Analisis}

DFA menggambarkan adanya pengaruh lingkungan sebagai kompetisi usaha, kejadian di pasar modal, dan sejumlah regulasi yang berlaku sehingga berdampak pada pengelolaan asetliabilitas perusahaan.

Pada tahap simulasi, model yang telah terbentuk dianalisis melalui berbagai arah yang memungkinkan. Pada tahap ini, banyaknya simulasi akan dapat meningkatkan kualitas hasil, dalam rangka mencapai keseluruhan hasil distribusi disamping angka-angka estimasi. Tahap analisis dan skenario yang tidak memenuhi syarat akan dibuang. Pada tahan interpretasi, strategi yang merugikan dan membahayakan dapat difilterisasi sehingga hanya ada skenario yang menguntungkan perusahaan. Tahap verifikasi adalah tahap terakhir dan tahap penentuan seberapa besar deviasi yang terjadi antara hasil simulasi dengan kenyataan yang terjadi.
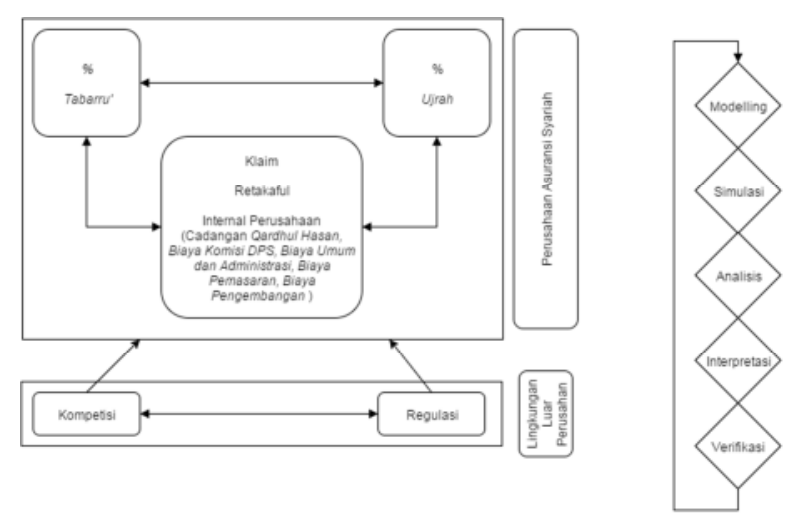
Punwocaroko, et al/Jurnal Ekonomi Syariah Teori dan Terapan Vol. 3 No. 2 Februari 2016:158-172; ANALISIS KOMPOSISI IDEAL DANA TABARRU'-UJRAH METODE DYNAMIC FINANCIAL ANALYSIS PERUSAHAAN ASURANSI JIWA SYARIAH DI INDONESIA

Gambar 4.

Pengembangan Konsep Dynamic

Financial Analysis yang telah disesuaikan berdasarkan keperluan penelitian

Puspitasari (2011:9-11) membuat serangkaian tahapan studi simulasi yang digunakan pada DFA meliputi:

1. Mencari sub sistem yang berpengaruh signifikan terhadap sub sistem tabarru'. Tahap ini menggunakan analisis regresi dengan persamaan sebagai berikut .

$Y_{t}=a+\beta 1 X 1_{(t-1)}+\beta 2 X 2_{(t-1)}+\beta 3 X 3_{(t-1)}+\beta 4 X 4_{(t-}$

$1)+\beta 5 X 5_{(t-1)}+\beta 6 \times 6_{(t-1)}+\beta 7 X 7_{(t-1)}+e$

Dimana :

\begin{tabular}{|c|c|}
\hline$Y \dagger$ & = komposisi tabarru' \\
\hline a & $=$ intersep \\
\hline$\beta 1, \beta 2$ & $=$ koefisien \\
\hline $\mathrm{X} 1$ & = variabel klaim \\
\hline$x 2$ & = variabel retakaful \\
\hline & $=\quad$ variabel \\
\hline
\end{tabular}

Qardhul Hasan

$$
\begin{array}{ll}
\text { X4 } & \text { = variabel biaya komisi DPS } \\
\text { X5 } & \text { = variabel biaya umum dan }
\end{array}
$$

administrasi

X6 = variabel biaya

pemasaran

X7 $\quad$ variabel biaya

pengembangan

$\mathrm{e}=$ error

2. Menentukan asumsi koefisien adjustment factor terhadap standar deviasi. Karena koefieien adjustment factor jugga disimulasikan pada range 0,1-0,5 maka diberlakukan angka random dengan asumsi yang terdapat pada tabel 3.1.
Tabel 4.

Asumsi Koefisien Adjustment Factor

\begin{tabular}{|c|c|}
\hline $\begin{array}{c}\text { Angka } \\
\text { Random }\end{array}$ & $\begin{array}{c}\text { Koefisien Adjustment } \\
\text { Factor (a) }\end{array}$ \\
\hline$x<0,2$ & 0,1 \\
\hline $0,2<x<0,4$ & 0,2 \\
\hline $0,4<x<0,6$ & 0,3 \\
\hline $0,6<x<0,8$ & 0,4 \\
\hline$x>0,8$ & 0,5 \\
\hline
\end{tabular}

3. Membuat

kriteria

untuk pengkategorian hasil simulasi dengan kriteria tinggi, sedang, dan rendah. Dalam melakukan tahapan ini maka dilakukan penghitungan upper control limit(UCL) dan lower control limit (LCL) dengan persamaan berikut :

$$
\begin{aligned}
& U C L=x+\alpha \sigma \\
& L C L=x-\alpha \sigma
\end{aligned}
$$

Dimana $\quad \boldsymbol{x}=$ rata - rata data sampel $\boldsymbol{\alpha}=$ koefisien penyesuaian thd standar dev. $\boldsymbol{\sigma}=$ standar deviasi

Setelah itu menentukan poin estimasi untuk masing-masing kategori tinggi, sedang, dan rendah yang disajikan dalam tabel 3.2.

Tabel 5.

Estimasi kategori Tinggi, Sedang, dan Rendah

\begin{tabular}{|c|c|}
\hline Poin Estimasi Kategori & Persamaan \\
\hline Tinggi & Rumus UCL \\
\hline Sedang & $\frac{(U C L+L C L)}{2}$ \\
\hline Rendah & Rumus LCL \\
\hline
\end{tabular}


Punwocaroko, et al/Jurnal Ekonomi Syariah Teori dan Terapan Vol. 3 No. 2 Februari 2016:158-172; ANALISIS KOMPOSISI IDEAL DANA TABARRU'-UJRAH METODE DYNAMIC FINANCIAL ANALYSIS PERUSAHAAN ASURANSI JIWA SYARIAH DI INDONESIA

4. Melakukan simulasi dengan menggerakkan angka random komputer untuk variabel yang terbukti berpengaruh signifikan terhadap komposisi tabarru'. Simulasi pada proses ini menggunakan skenario pada tabel 3.3.

Tabel 6.

Skenario Kategori Angka Random

\begin{tabular}{|c|c|}
\hline Angka Random (x) & $\begin{array}{c}\text { Kategori Pola } \\
\text { Estimasi }\end{array}$ \\
\hline $\begin{array}{c}\mathrm{x}<\% \text { probabilitas kategori } \\
\text { rendah }\end{array}$ & Rendah \\
\hline $\begin{array}{c}\text { \% prob kategori rendah }<\mathrm{x} \\
<\% \text { prob kategori sedang }\end{array}$ & Sedang \\
\hline $\begin{array}{c}\text { \% prob kategori sedang }< \\
\mathrm{x}<\% \text { prob kategori tinggi }\end{array}$ & Tinggi \\
\hline
\end{tabular}

Dimana \% probabilitas dari masing-masing kategori diperoleh dengan persamaan :

$$
\% \text { prob. kategori }=\frac{\Sigma K S}{n}
$$

Dimana: $\quad \Sigma \mathrm{KS}=$ jumlah kategori sama pada populasi data sampel

$$
n=\text { jumlah data sampel }
$$

pada proses simulasi, setiap kali melakukan iterasi dengan menggerakkan angka random, hasil dimulasi harus dibekukan dulu (disimpan pada sheet atau lembar kerja lain) agar tidak terganggu dengan proses iterasi (pengulangan) selanjutnya.

5. Dengan diperolehnya hasil simulasi dengan probabilitas rendah, sedang, tinggi maka akan dapat diketahui probabilitas presentase tabarru' yang akan muncul.
6. Penghitungan presentase tabarru' yang akan muncul menggunakan persamaan sebagai berikut.

$Y_{t+1}=a+b X 1_{(t-1)}+c X 2_{(t-1)}+\ldots .$.

Dimana :

Y $\quad=$ Presentase tabarru' yang akan muncul

$\begin{array}{ll}\mathrm{a} & =\text { intercept hasil regresi } \\ \mathrm{b} & =\text { koefisien elastisitas }\end{array}$ variabel ke-1 yang berpengaruh signifikan

C $=$ koefisien elastisitas veriabel ke-2 yang berpengaruh signifikan $\mathrm{Xl}(\mathrm{t}-1)=$ variabel ke-1 pada $\mathrm{t}-1$ hasil simulasi yang berpengaruh signifikan terhadap tabarru'

$\mathrm{X} 2(\mathrm{t}-1)=$ variabel ke-2 pada $t-1$ hasil simulasi yang berpengaruh signifikan terhadap tabarru'

7. Melakukan simulasi sebanyak 8 kali simulasi dengan masing-masing simulasi sebanyak $\quad 100$ kali iterasi (pengulangan).

8. Dari simulasi yang dilakukan maka akan diketahui probabilitas tertinggi yang akan muncul untuk presentase tabarru' untuk periode yang akan datang.

9. Mengestimasi proforma laporan keuangan yaitu melakukan estimasi pada masing-masing komponen yang digunakn untuk menghitung kinerja kevangan dimana yang digunakan adalah Risk Based Capital (RBC) Dana Tabarru' dan Return on Investment (ROI) Dana Pemegang Saham.

10.Melakukan pemisahan dana dengan komposisi tabarru' dan ujrah yang 
Punwocaroko, et al/Jurnal Ekonomi Syariah Teori dan Terapan Vol. 3 No. 2 Februari 2016:158-172; ANALISIS KOMPOSISI IDEAL DANA TABARRU'-UJRAH METODE DYNAMIC FINANCIAL ANALYSIS PERUSAHAAN ASURANSI JIWA SYARIAH DI INDONESIA

memiliki probabilitas akan muncul pada periode yang akan datang.

11.Memghitung kinerja keuangan yang digunakan, RBC DPT dan ROI DPS.

\section{Hasil dan Pembahasan}

\section{Uji Asumsi Klasik}

Uji asumsi klasik dilakukan setelah ditemukan dua variabel yang berpengaruh signifikan terhadap tabarru' pada uji regresi linear berganda tahap pertama yakni klaim dan retakaful. Uji Asumsi klasik yang dilakukan antara lain Uji normalitas, uji autokorelasi, uji heteroskedastisitas, dan uji multikolinearitas. Dari hasil keseluruhan uji asumsi klasik telah memenuhi kriteria sebagai model regresi yang baik.

Tabel 7.

Rekapitulasi Uji Asumsi Klasik

\begin{tabular}{|c|c|c|c|c|}
\hline $\begin{array}{l}N \\
O\end{array}$ & $\begin{array}{c}\text { UJI } \\
\text { ASUMSI } \\
\text { KLASIK }\end{array}$ & JENIS & HASIL & $\begin{array}{c}\text { KEPUTUS } \\
\text { AN }\end{array}$ \\
\hline 1 & $\begin{array}{c}\text { Uji } \\
\text { Normali- } \\
\text { tas }\end{array}$ & $\begin{array}{l}\text { Uji } \\
\text { Kolmo } \\
\text { grov- } \\
\text { Smirn } \\
\text { ov }\end{array}$ & 0.141 & $\begin{array}{l}\text { Data } \\
\text { terdistri } \\
\text { busi } \\
\text { normal }\end{array}$ \\
\hline 2 & $\begin{array}{c}\text { Uji } \\
\text { Autoko- } \\
\text { relasi }\end{array}$ & $\begin{array}{l}\text { Run } \\
\text { Test }\end{array}$ & 0.059 & $\begin{array}{c}\text { Tidak } \\
\text { terjadi } \\
\text { Autokor } \\
\text { elasi }\end{array}$ \\
\hline 3 & $\begin{array}{c}\text { Uji } \\
\text { Heterosk } \\
\text { edasti- } \\
\text { sitas }\end{array}$ & $\begin{array}{l}\text { Uji } \\
\text { Glejs- } \\
\text { er }\end{array}$ & $\begin{array}{c}0.054 \& \& \\
0.457\end{array}$ & $\begin{array}{c}\text { Terjadi } \\
\text { Homok } \\
\text { edastisit } \\
\text { as/Tida- } \\
\text { k } \\
\text { Heterok } \\
\text { edastisit } \\
\text {-as }\end{array}$ \\
\hline 4 & $\begin{array}{c}\text { Uji } \\
\text { Multikoli } \\
\text { nearita-s }\end{array}$ & $\begin{array}{c}\text { VIF\&T } \\
\text { oleran } \\
c-e\end{array}$ & $\begin{array}{c}1,638 \& \& \\
0.610\end{array}$ & $\begin{array}{c}\text { Tidak } \\
\text { terjadi } \\
\text { Multikoli }\end{array}$ \\
\hline
\end{tabular}

\begin{tabular}{|c|c|c|c|c|}
\hline $\begin{array}{l}N \\
O\end{array}$ & $\begin{array}{c}\text { UJI } \\
\text { ASUMSI } \\
\text { KLASIK }\end{array}$ & JENIS & HASIL & $\begin{array}{c}\text { KEPUTUS } \\
\text { AN }\end{array}$ \\
\hline & & & & nearitas \\
\hline
\end{tabular}

Sumber : Data Olahan Peneliti

Serangkaian Dynamic Financial Analysis

a. Uji Regresi Tahap Dua

$Y=4684,995+1,423$ Klaim $+0,627$ Retakaful $+e$

Kedua variabel memiliki pengaruh yang berbanding lurus dengan proporsi tabarru'. Hal ini mengindikasikan bahwa proporsi tabarru' tidak mengalami penurunan ketika klaim dan retakaful terjadi.

\section{b. Asumsi Koefisien Adjustment Factor}

Koefisien Adjustment Factor terhadap standar deviasi digunakan untuk menentukan standar deviasi yang akan digunakan dalam perhitungan UCL (Upper Control Limit) dan LCL (Lower Control Limit) untuk proses random selanjutnya. Terlihat bahwa standar deviasi yang digunakan pada proses selanjutnya adalah 0,4 dengan total kemunculan 176 kali.

Tabel 8.

Analisis Regresi Linier Berganda

\begin{tabular}{|c|c|}
\hline Std. Deviasi & $\begin{array}{c}\text { Total Jumlah } \\
\text { Kemunculan }\end{array}$ \\
\hline 0.1 & 147 \\
\hline 0.2 & 164 \\
\hline 0.3 & 161 \\
\hline 0.4 & 176 \\
\hline 0.5 & 152 \\
\hline
\end{tabular}

Sumber: Data Olahan Peneliti

c. Kriteria Pengkategorian Hasil Simulasi

Tabel 9.

Kriteria Kategori Simulasi

\begin{tabular}{|c|c|c|c|c|}
\hline $\begin{array}{c}\text { KTG } \\
\text { RI }\end{array}$ & PERS. & TBR & KLAIM & RTKFL \\
\hline
\end{tabular}


Punwocaroko, et al/Jurnal Ekonomi Syariah Teori dan Terapan Vol. 3 No. 2 Februari 2016:158-172; ANALISIS KOMPOSISI IDEAL DANA TABARRU'-UJRAH METODE DYNAMIC FINANCIAL ANALYSIS PERUSAHAAN ASURANSI JIWA SYARIAH DI INDONESIA

\begin{tabular}{|c|c|c|c|c|} 
High & UCL & 0,69 & $53.496,11$ & $\begin{array}{c}28.412,8 \\
7\end{array}$ \\
\hline Mid & $\begin{array}{c}\text { (UCL+ } \\
\text { LCL)/2 }\end{array}$ & 0,55 & $28.755,52$ & $\begin{array}{c}14.748,5 \\
4\end{array}$ \\
\hline Low & LCL & 0,41 & $4.014,93$ & $1.084,21$ \\
\hline
\end{tabular}

Sumber : Data Olahan Peneliti

\section{d. Skenario Angka Random}

Tabel 10.

Skenario Angka Random yang Muncul

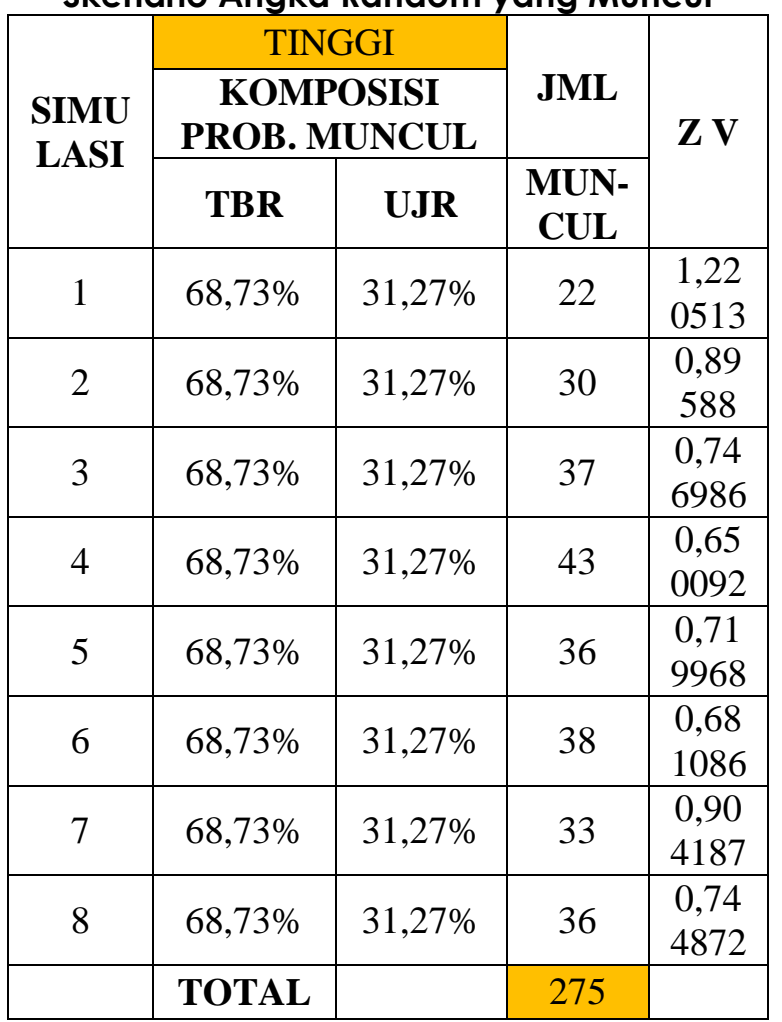

\begin{tabular}{|c|c|c|c|c|}
\hline \multirow{2}{*}{$\begin{array}{c}\text { SIMU } \\
\text { LASI }\end{array}$} & \multicolumn{2}{|c|}{ SEDANG } & & \\
\cline { 2 - 5 } & KOMPOSISI & JML & $\mathbf{Z ~ V}$ \\
\cline { 2 - 5 } & TBR & UJR & $\begin{array}{c}\text { MUN } \\
\text { CUL }\end{array}$ & \\
\hline 1 & $54,97 \%$ & $45,03 \%$ & 38 & $\begin{array}{c}1,22 \\
0513\end{array}$ \\
\hline 2 & $54,97 \%$ & $45,03 \%$ & 35 & $\begin{array}{c}0,89 \\
588\end{array}$ \\
\hline 3 & $54,97 \%$ & $45,03 \%$ & 31 & $\begin{array}{c}0,74 \\
6986\end{array}$ \\
\hline 4 & $54,97 \%$ & $45,03 \%$ & 26 & $\begin{array}{c}0,65 \\
0092\end{array}$ \\
\hline 5 & $54,97 \%$ & $45,03 \%$ & 32 & $\begin{array}{c}0,71 \\
9968\end{array}$ \\
\hline
\end{tabular}

\begin{tabular}{|c|c|c|c|c|}
\hline \multirow{2}{*}{$\begin{array}{l}\text { SIMU } \\
\text { LASI }\end{array}$} & \multicolumn{2}{|c|}{ SEDANG } & & \\
\hline & \multicolumn{2}{|c|}{$\begin{array}{c}\text { KOMPOSISI } \\
\text { PROB. MUNCUL }\end{array}$} & JML & $\mathbf{Z ~ V}$ \\
\hline 6 & $54,97 \%$ & $45,03 \%$ & 33 & $\begin{array}{l}0,68 \\
1086\end{array}$ \\
\hline 7 & $54,97 \%$ & $45,03 \%$ & 28 & $\begin{array}{l}0,90 \\
4187\end{array}$ \\
\hline 8 & $54,97 \%$ & $45,03 \%$ & 20 & $\begin{array}{l}0,74 \\
4872\end{array}$ \\
\hline \multicolumn{3}{|c|}{ TOTAL } & 243 & \\
\hline
\end{tabular}

\begin{tabular}{|c|c|c|c|c|}
\hline \multirow{3}{*}{$\begin{array}{l}\text { SIMU } \\
\text { LASI }\end{array}$} & \multicolumn{2}{|c|}{ RENDAH } & \multirow[b]{2}{*}{ JML } & \multirow{3}{*}{$\mathbf{Z V}$} \\
\hline & \multicolumn{2}{|c|}{$\begin{array}{c}\text { KOMPOSISI } \\
\text { PROB. MUNCUL }\end{array}$} & & \\
\hline & $\begin{array}{c}\text { TABARR } \\
\text { U' }^{\prime}\end{array}$ & $\begin{array}{c}\text { UJRA } \\
\text { H }\end{array}$ & $\begin{array}{l}\text { MUN } \\
\text { CUL }\end{array}$ & \\
\hline 1 & $41,20 \%$ & $\begin{array}{c}58,80 \\
\%\end{array}$ & 40 & $\begin{array}{l}1,22 \\
0513\end{array}$ \\
\hline 2 & $41,20 \%$ & $\begin{array}{c}58,80 \\
\%\end{array}$ & 35 & $\begin{array}{c}0,89 \\
588 \\
\end{array}$ \\
\hline 3 & $41,20 \%$ & $\begin{array}{c}58,80 \\
\%\end{array}$ & 32 & $\begin{array}{l}0,74 \\
6986\end{array}$ \\
\hline 4 & $41,20 \%$ & $\begin{array}{c}58,80 \\
\%\end{array}$ & 31 & $\begin{array}{l}0,65 \\
0092\end{array}$ \\
\hline 5 & $41,20 \%$ & $\begin{array}{c}58,80 \\
\%\end{array}$ & 32 & $\begin{array}{r}0,71 \\
9968\end{array}$ \\
\hline 6 & $41,20 \%$ & $\begin{array}{c}58,80 \\
\%\end{array}$ & 29 & $\begin{array}{l}0,68 \\
1086\end{array}$ \\
\hline 7 & $41,20 \%$ & $\begin{array}{c}58,80 \\
\%\end{array}$ & 39 & $\begin{array}{l}0,90 \\
4187\end{array}$ \\
\hline 8 & $41,20 \%$ & $\begin{array}{c}58,80 \\
\% \\
\end{array}$ & 29 & $\begin{array}{l}0,74 \\
4872 \\
\end{array}$ \\
\hline & TOTAL & & 267 & \\
\hline
\end{tabular}

Sumber : Data Olahan Peneliti

Berdasarkan hasil simulasi di atas

maka komposisi tabarru'-ujrah yang memiliki akumulasi probabilitas paling tinggi (komposisi yang sering muncul saat simulasi) adalah komposisi tabarru'-ujrah kategori tinggi dengan nilai komposisi sebesar $68,73 \%$ : 31,27\%. Mengingat bahwa dalam penelitian ini digunakan alat berupa simulasi sebagai pengambilan keputusan pada sebagian besar alat DFA pada aplikasinya maka komposisi 
Purwocaroko, et al/Jurnal Ekonomi Syariah Teori dan Terapan Vol. 3 No. 2 Februari 2016:158-172; ANALISIS KOMPOSISI IDEAL DANA TABARRU'-UJRAH METODE DYNAMIC FINANCIAL ANALYSIS PERUSAHAAN ASURANSI JIWA SYARIAH DI INDONESIA

tabarru'-ujrah inilah yang kemudian disebut sebagai komposisi ideal tabarru'ujrah. Karena nilainya yang sering muncul dalam simulasi yang ditunjukkan oleh nilai akumulasi sebesar 275 .

\section{e. Estimasi Proforma Laporan Keuangan}

Tabel 11. Tabel Kombinasi berdasarkan forecasting

\begin{tabular}{|c|c|c|c|c|}
\hline kombinasi & $\begin{array}{c}\text { \% } \\
\text { TBR }\end{array}$ & \%UJR & $\begin{array}{c}\text { \%RBC } \\
\text { DPT }\end{array}$ & $\begin{array}{c}\text { \%ROI } \\
\text { DPS }\end{array}$ \\
\hline HIGH-HIGH & 53 & 47 & 62 & 3 \\
\hline HIGH-MED & 49 & 51 & 57 & -15 \\
\hline HIGH-LOW & 44 & 56 & 52 & -33 \\
\hline MED-HIGH & 35 & 65 & 41 & -71 \\
\hline MED-MED & 30 & 70 & 35 & -90 \\
\hline MED-LOW & 26 & 74 & 30 & -108 \\
\hline LOW-HIGH & 16 & 84 & 19 & -146 \\
\hline LOW-MED & 12 & 88 & 14 & -164 \\
\hline LOW-LOW & 7 & 93 & 9 & -182 \\
\hline
\end{tabular}

Sumber : Data Olahan Peneliti

Pada saat kondisi kombinasi pertama yakni antara klaim tinggi dan retakaful yang tinggi membentuk komposisi tabarru'-ujrah yang cukup ideal bagi keduanya dengan angka 53\%:47\%. Maknanya klaim dan retakaful yang tinggi dapat menyebabkan komposisi yang cukup ideal.

Pada kondisi kombinasi kesembilan, yakni antara klaim rendah dan retakaful yang rendah. Angka menunjukkan 7\% untuk komposisi tabarru' dan 93\% untuk komposisi ujrah. Kedua komposisi tersebut sama sekali tidak ideal. Artinya setiap kontribusi peserta yang masuk ke dalam perusahaan asuransi jiwa syariah sebagian besar akan menjadi ujrah.

Pada kondisi pertama, ROI DPS menunjukkan angka positif. Selebihnya hingga kondisi kesembilan ROI menunjukkan angka negatif yang cukup besar.Berdasarkan hasil Forecasting yang dilakukan, maka ROI DPS menjadi minus. Hal itu memang didasari karena sejumlah data historis antara rentang tahun 20122014, sejumlah perusahaan mengalami rugi yang cukup besar.

Berdasarkan data di atas, Perusahaan Asuransi Jiwa Syariah menentukan komposisi tabarru' terlebih dahulu daripada komposisi ujrah. Hal itu sesuai dengan syariah dan pengelolaan risiko yang benar. Sesuai syariah, karena perusahaan asuransi jiwa syariah lebih mengutamakan kepentingan peserta asuransi daripada kepentingan perusahaan. Sementara, sesuai dengan pengelolaan risiko adalah perusahaan memperoleh banyak sekali dana peserta tabarru' untuk keperluan klaim peserta, dengan demikian perusahaan asuransi jiwa syariah memiliki kesempatan yang luas untuk menginvestasikan dana peserta tabarru' pada instrumen bagi hasil dan tidak perlu mengeluarkan cadangan qardhul hasan sebagai bentuk bantuan kepada dana peserta tabarru' jika klaim terlalu berlebihan.

\section{SIMPULAN}


Purwocaroko, et al/Jurnal Ekonomi Syariah Teori dan Terapan Vol. 3 No. 2 Februari 2016:158-172; ANALISIS KOMPOSISI IDEAL DANA TABARRU'-UJRAH METODE DYNAMIC FINANCIAL ANALYSIS PERUSAHAAN ASURANSI JIWA SYARIAH DI INDONESIA

Hasil simulasi menunjukkan bahwa komposisi ideal tabarru'-ujrah terletak pada komposisi 68,73\%:31,27\%.

Sementara itu, komposisi ideal tersebut kemudian diujikan kepada kinerja keuangan yaitu Risk Based Capital Dana Peserta Tabarru' (RBC DPT) dan Return On Investment Dana Pemegang Saham (ROI DPS). Terdapat beberapa fenomena yang terjadi pada penelitian ini saat tahap pengujian ini. Fenomena yang pertama adalah penetapan komposisi tabarru' yang menunjukkan angka di bawah 50\%.

Fenomena kedua adalah perusahaan asuransi jiwa syariah secara industri akan menetapkan ujrah yang besar di setiap kontribusinya pada saat komposisi klaim dan retakaful pada posisi yang rendah. Fenomena ketiga yang terjadi adalah ROI DPS yang diterima hingga tahun akhir forecasting semakin menurun dan bahkan minus.

Penetapan komposisi ideal antara tabarru' dan ujrah haruslah memperhatikan sisi syariah dan pengelolaan risiko. Selain tabarru' harus ditentukan terlebih dahulu, dengan melimpahnya tabarru' maka perusahaan asuransi jiwa syariah menghadapi risiko pengelolaan klaim yang jauh lebih rendah.

\section{DAFTAR PUSTAKA}

Fatwa DSN-MUI No. 52/ DSN-MUI/III/2006 Tentang Akad Wakalah Bil Ujrah pada Asuransi dan Reasuransi Syariah
Fatwa DSN-MUI No. 53/DSN-MUI/III/2006 Tentang Akad Tabarru' pada Asuransi Syariah

Hasan, Nurul IChasan. 2014. Pengantar Asuransi Syariah. Referensi (Gaung Persada Press Group)

Hendriksen, Eldon S.. 1977. Accounting Theory. Richard D. Irwin, Inc

Kam, Vernon. 1990. Accounting Theory 2nd Edition. New York: Wiley

Peraturan Menteri Keuangan No. 11/PMK.010/2011 Tentang Kesehatan Kevangan Usaha Asuransi dan Usaha Reasuransi dengan Prinsip Syariah

Puspitasari, Novi. 2011. Analisis Keuangan Dinamis Pada Manajemen Keuangan Bisnis Asuransi Umum Syariah. Vol 10: hal 127-144

\section{Model Proporsi}

Tabarru' dan Ujrah Pada Bisnis Asuransi Umum Syariah di Indonesia. Vol 9 No. 1 Juni 2012:hal 43-55. Jurnal Akuntansi dan Keuangan Indonesia , 2011. Shari'ah Split Fund Theory Sebagai Refeksi Praktik Pemisahan Dana Bisnis Asuransi Umum Syariah. Disertasi tidak diterbitkan. Pascasarjana Fakultas Ekonomi Univ. Brawijaya Malang 2015. Manajemen Asuransi Syaiah. UII Press

Soemitra, Andri. 2009. Bank \& Lembaga Kevangan Syariah. Kencana

Sudarsono, Heri. 2012. Bank dan Lembaga Kevangan Syariah : Deskripsi dan Ilustrasi. Ekonisia 